\title{
Einfache Analyse des Wollfettes.
} von

\section{Hugo Bornträger.}

Das Wollfett ist bekanntlich das bei der Wollwäscherei ans den Waschwassern mit Schwefelsäure abgeschiedene Fett; dasselbe enthält somit liein Glycerin mehr, sondern nur freie Fettsäuren. In der Regel handelt es sich nur um Ermittelung des Gehaltes an:

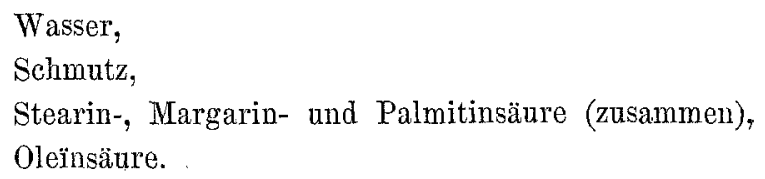

1. Bestimmung von Wasser und Schmutz:

Man trocknet $1 \mathrm{~g}$ des Fettes in einem Becherglase bei $110^{\circ} \mathrm{C}$. bis zum constanten Gewichte, alsdann löst man das Fett in etwa $50 \mathrm{cc}$ heissem, absolutem Alkohol auf, filtrirt durch ein gewogenes Filter und trocknet nach dreimaligem Nachwaschen mit heissem Alkohol das Filter mit dem Schmutze bei $110^{\circ} \mathrm{C}$.

2. Bestimmung der festen Fettsäuren; Stearin-, Palmitin- und Margarin-Säure :

Man engt die alkoholische Lösung auf circa $50 \mathrm{cc}$ ein und lässt 24 Stunden in der Kälte stehen; es scheiden sich alle festen Fettsäuren aus, während Oleïnsäure in Alkohol gelöst bleibt. Man giesst $a b$, wäscht mit kaltem Alkohol dreimal nach und trocknet die festen Fettsäuren bei $105^{0} \mathrm{C}$. bis zum constanten Gewichte.

Die Differenz von Wasser, Schmutz, den festen Fettsäuren und 100,0 ergibt die Oleïnsäure. die man natürlich auch direct durch Verdunsten des Alkohols und Trocknen bei $100^{\circ} \mathrm{C}$. bis zum constanten Gewichte bestimmen kann.

Selbstredend kann man auch nach dieser Methode fast jedes Fett rasch untersuchen, zum Beispiel Knochenfett, Palmöl, Cocosfett, Cacaobutter u. s. w.

Ein so untersuchtes Wollfett ergab:

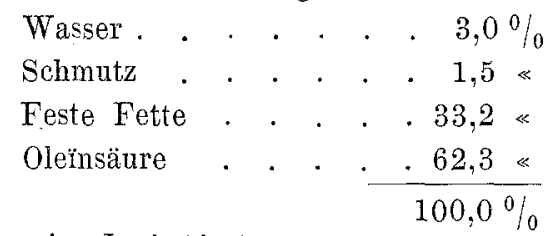

Hannover, im Juni 1900. 